AperTO - Archivio Istituzionale Open Access dell'Università di Torino

How hydromorphological constraints and regulated flows govern macroinvertebrate communities along an entire lowland river

This is a pre print version of the following article:

Original Citation:

Availability:

This version is available http://hdl.handle.net/2318/1727843

since 2020-02-19T16:46:52Z

Published version:

DOI:10.1002/eco.1354

Terms of use:

Open Access

Anyone can freely access the full text of works made available as "Open Access". Works made available under a Creative Commons license can be used according to the terms and conditions of said license. Use of all other works requires consent of the right holder (author or publisher) if not exempted from copyright protection by the applicable law. 


\section{How hydromorphological constraints and regulated 2 flows govern macroinvertebrate communities along an entire lowland river?}

4 5
S. Guareschi, ${ }^{1,3}$ A. Laini, ${ }^{1,2 *}$ E. Racchetti, ${ }^{1}$ T. Bo, ${ }^{4}$ S. Fenoglio, ${ }^{4}$ and M. Bartoli ${ }^{1}$

1 Department of Environmental Sciences, University of Parma, Viale G.P. Usberti, 33/A 43124 Parma, Italy

2 Institute of Agricultural and Environmental Chemistry, "Sacro Cuore" Catholic University, Via Emilia Parmense 84, 29100 Piacenza, Italy

3 Department of Ecology and Hydrology, University of Murcia, Espinardo Campus 30100 Murcia, Spain

4 Department of Science and Technological Innovation, University of Piemonte Orientale "A. Avogadro" Via T. Michel 11, 15121 Alessandria, Italy

*Correspondence to: Dr. Alex Laini

Department of Environmental Sciences, University of Parma

Viale G.P. Usberti, 33/A

43124 Parma, Italy.

E-mail: alex.laini@nemo.unipr.it

Keywords: regulated river; lowland river; macroinvertebrate community; ecological traits; indicator taxa; hydromorphological constraints

Running title: Hydromorphological constraints on macroinvertebrate communities 


\section{ABSTRACT}

46 Macroinvertebrates' response to hydromorphological alterations and regulated flows along lowland 47 rivers is still poorly known despite ecohydrology's fundamental role in river science. Along the

48 Oglio River (Northern Italy), several water abstractions and dams break it into segments with

49 varying hydraulic and morphological properties. Three types of a priori different environments

50 were identified (dammed, downstream and free flowing sections) and macroinvertebrate

51 communities were sampled from each zone. This study aimed: I) to investigate patterns of

52 macroinvertebrate communities along a regulated lowland river by testing the a priori zones; II) to

53 find macroinvertebrate taxa that served as indicators of the various hydrological conditions and III)

54 to verify hydromorphological control over ecological macroinvertebrate traits resulting in different

55 trait values in each identified zone. Macroinvertebrate community was characterised in a total of 63

56 stations by means of two distinct[sf1] quantitative approaches, each exploring a surface of $0.5 \mathrm{~m}^{2}$.

57 The lowest richness values were found in dammed sites that tended toward lentic conditions.

58 Ecnomidae (dammed zones), Limoniidae (downstream zones) and Heptageniidae (free flowing

59 section) were identified as the best indicators of varying hydrological conditions. As suggested by

60 the results of 4th Corner Method environmental constraints define communities with different

61 ecological traits. These results highlight hydromorphological control over macroinvertebrate

62 community structure and reflect how regulated flows affect the Oglio River in terms of biodiversity,

63 indicator taxa and ecological traits. The authors wish to stress the importance of considering the

64 ecological effects of dams and impoundments on river systems in upstream areas as well as

65 downstream. 
Rivers and streams are among the most vulnerable and simultaneously exploited ecological systems on our planet (Allan and Castillo 2007). Humans have broadly altered river systems' hydrology through impoundments and diversions to meet their water, energy, and transport needs. In particular, dam construction has increased exponentially in recent decades, especially during the period 1960-1990 (Rosenberg et al., 2000). Rivers and streams are shaped by their hydrology, which sets bottom features, the timing of flooding, transport of solids and dissolved materials, metabolic rates and biological communities (Allan and Castillo 2007). Any alterations in hydrology, such as those resulting from dams, have consequences for a number of lotic ecosystem properties. This latter issue seems obvious, but the implications of hydrological regime, river continuity and morphological conditions (together termed hydromorphology) for river and stream management were scarcely considered for a long time. Currently, there is a need to understand the ecological effects of a wide range of changes in physical habitat, as rivers are increasingly exploited, regulated or otherwise modified through flood-defence engineering, impoundments, restoration, climate change and the spread of alien species (Vaughan et al., 2009). The need for studies linking hydromorphology and ecological response is a priority for river research and management that requires clearly stated hypotheses and adequate sampling programmes that are able to develop robust flow alteration-ecological response relationship (Vaughan et al., 2009; Poff and Zimmerman 88 2010).

Hydromorphological elements and their assessment in lotic ecosystems were introduced recently in European legislation, with the Water Framework Directive (European Commission 2000) as a supporting tool for the comprehension of biological and chemical features. Unaltered

92 hydromorphology is generally coupled with an elevated ecological status, and vice-versa (European 93 Commission 2000).

Dam construction leads to a variety of demonstrated effects in stream hydraulics and properties, like the alteration of sediment transport (Ward and Stanford 1983, 1987; Syvitski et al., 2005), inundation of terrestrial systems (Nilsson and Berggren 2000), fragmentation of riparian plant distribution (Jansson et al., 2000), enhancement of greenhouse gas emissions (St Louis et al., 2000), changes in thermal regimes and water chemical composition (Armitage 1984; Olden and Naiman 2010; Lessard and Hayes 2003) as well as a possible regime shift, from net heterotrophy to net autotrophy (Pinardi et al., 2011). Furthermore, aquatic biodiversity seems to respond to hydraulic disturbance by changing community structures and resistance to invasion of exotic species (Stanford et al., 1996; Bunn and Arthington 2002; Poff et al., 2007). Different studies (Copp 1990; Irz et al., 2006) reported a transition from lotic to lentic fish communities in dammed sites as well as increased in exotic and lake-adapted taxa (Pringle et al., 2000). However, there are few 
similar studies focussing [sf2] on other aquatic taxa. The way the whole macroinvertebrate community respond to hydromorphological alterations and regulated flows in the long term, largescale and lowland rivers has been poorly explored. Many researchers have investigated the ecohydrological changes that occur below a single dam, but few studies have examined changes in macroinvertebrate communities encompassing an entire river unit (Heppner and Loague 2008; Zolezzi et al., 2011). Hydraulic stream conditions and other hydrologic factors, including a combination of current velocity, depth, surface slope and substrate roughness, instead seem to be important factors for invertebrate zonation patterns (Rempel et al., 2000, Brooks et al., 2005, Kennen et al., 2010) and benthic ecology (Carling 1992). Nevertheless, the consequences of streams management and invertebrate hydraulic preferences are generally better known in small streams than in medium or large rivers (Mérigoux et al., 2009), which is probably due to the complexity of these systems (Sparks 1995).

The effects of dams and barriers on macroinvertebrate communities are important because of the role that macroinvertebrates play in the functions and dynamics of stream ecosystems (Merritt $e t$ al., 1984; Merritt and Lawson 1992). Dam use and the intensive exploitation of rivers, particularly in northern Italy, dates back to 1900 . They were historically designed with little consideration for ecological effects such as migration pathways, minimum flow releases or hydropeaking problems. Here, as in many Mediterranean countries, rivers were converted into discontinuous systems with alternating or adjacent segments characterised by varying hydrologic conditions.

In this study three types of environments were identified a priori along the course of the regulated lowland Oglio River: a lentic stretch (dammed: upstream of the dams or weirs), a streamlike (downstream: downstream dams or water abstraction infrastructures) and a river-like section (free flowing) and macroinvertebrate communities were studied in each part. The main hypothesis is that macroinvertebrate community patterns are clearly addressed by different flow conditions affecting taxa richness, indicator families and ecological traits.

In order to contribute to the knowledge of hydromorphological constraints and regulated flows on macroinvertebrate communities, this study aims: I) to investigate patterns of macroinvertebrate communities along a lowland flow regulated river, testing a priori zonation; II) to find macroinvertebrate taxa that would serve as indicators of different hydrological conditions and III) to verify environmental and hydromorphological control over macroinvertebrate ecological traits resulting in different trait values in each zone.

\section{METHODS}

Study area

This study was carried out along the entire Oglio River (Lombardia, northern Italy), a man- 
regulated watercourse of $154 \mathrm{~km}$ (Fig. 1). This river originates from an Alpine lake, the Lake Iseo (185 m a.s.1.), and flows into the Po River (16 m.a.s.1.). Water flow in the Oglio River is regulated by the Sarnico dam, at the southern extreme of Lake Iseo; regulation aims at the production of electricity and the maintenance of a water reserve in the upstream lake for irrigation purposes. The catchment of the Oglio River occupies an area of $3840 \mathrm{~km}^{2}$, mostly exploited for agricultural activities (67\%) and animal farming (about 600,000 cows and over 2,100,000 pigs); the human population comprises roughly $1,100,000$ inhabitants.

The Oglio River suffers from various pressures. Briefly, intensive agriculture and farming have resulted in diffuse nitrogen pollution that affects surface and groundwater (Soana et al., 2011; Laini et al., 2011). The river itself has been heavily altered from its pristine status due to multiple agricultural and industrial water uses and from the construction of hydropower plants, low head dams and banks. Water diversions for irrigation date back to 1500 and are mainly located along the upper $29 \mathrm{~km}$ long reach; the sum of their water concession equals the average historical flow of the river (about $80 \mathrm{~m}^{3} \mathrm{~s}^{-1}$ ), which means that the water flow could be entirely diverted. The realisation of hydropower plants is a more recent issue that dates back to 1950; six plants are operating at present, all located in the same upper reach mentioned above where the river is generally confined to a single channel, disconnected from its floodplain and with reduced sinuosity. Altered flow regime and damming are probably major causes of habitat heterogeneity loss. Hydraulic infrastructures result in variable riverbed widths (from $<30$ to about $100 \mathrm{~m}$ ) and in variable water depths, from several meters upstream from the dams, to a few centimeters downstream from the water abstraction. The Oglio River has the typical features of a plain river, with gentle slopes and moderate water flow. The river substrate only partially varies along the longitudinal gradient from a typical gravel-dominated substrate to a fine sand-dominated substrate in the lowland areas. This is due to the presence of hydraulic infrastructures in the upper sections that affect the gravel substrate converting in silt and macrophyte-dominated substrate upstream from the dams.

\section{Macroinvertebrate and environmental data}

The macroinvertebrate community was sampled seasonally from July 2009 to May 2010 in a number of representative sites located along the Oglio River (Fig.1). Sampling sites, seasonally investigated, varied from a minimum of 15 to a maximum of 18. A few sites (mainly in dammed and free flowing zones) do not present a complete seasonal series due to vandalism or excess flow/floods. Sampling strategy reflected an a priori idea to split the water course into three environment types: i) dammed sites (basins upstream hydropower plants or low head dams); ii) sites immediately downstream to those described as dammed and iii) free flowing section in the lowland, meandering zone. Macrofauna community was characterised in a total of 63 stations by means of 
two distinct quantitative approaches, each exploring a surface of $0.5 \mathrm{~m}^{2}$. At those sites belonging to dammed and free flowing zones artificial substrates were employed whilst at sites belonging to downstream zones a Surber net was used. At each station downstream hydropower plants or dams a total of 10 Surber units ( 1 surber unit $=0.05 \mathrm{~m}^{2}$, with $500 \mu \mathrm{m}$ mesh size net) were collected on each date by stirring and removing surface sediments and stones to remove any attached invertebrates. Explored areas within each station were proportional to the relative surface of all the microhabitats identified, according to Buffagni and Erba (2007).

$$
\text { Reliable and accurate collection of macroinvertebrates presents a certain degree of difficulty }
$$
in deep sections of upstream dams and where flows are elevated. Here, the use of artificial substrates (Hester-Dendy modified e.g. Cairns and Dickson 1971; Battegazzore et al., 1995) can represent a valid alternative to the Surber net (Solimini et al., 2000; Buffagni et al., 2007). Multiple-plate artificial substrates (hereinafter called AS) summing a total colonisable area of 0.5 $\mathrm{m}^{2}$, were thus employed at dammed and free flowing stations. These samplers were anchored and suspended with ropes close to the bottom, as detailed in Buffagni et al. (2007). They were left in situ for 1 month to allow complete colonization and thereafter carefully retrieved. Each sampler was placed in a white plastic tray, and macroinvertebrates were removed with forceps from the plates and trapped sediment. The macroinvertebrates dislodged in the process of removing the AS from the river were collected immediately downstream with a 500- $\mu \mathrm{m}$ mesh net and added to the sample. Macroinvertebrate samples and associated material, both from the Surber net or AS, were preserved in $70 \%$ ethanol and then examined under a stereoscope in the laboratory. All macroinvertebrate individuals were identified at family or genus level except for Hydracarina and Rissoidea gastropods. The sampling and processing effort at this taxonomic level allowed all groups from the invertebrate community to be investigated.

In all sampling dates and at all stations data on water flow, current velocity and depth were collected or provided by the Oglio Consortium (member of Alpine Lakes Controller Institutions, Civil Protection Department) (Table 1).

\section{Data analyses}

In this study two distinct quantitative approaches were used that contributed to the compilation of a large dataset. Different sampling methods can results in varying estimations of macrofauna abundance (Buffagni and Erba 2007), but they do not generally select among taxa so that presence/absence data are reliable with both approaches (Bo et al., 2007). However the use of different sampling methods for different habitats is reported in many other studies (Gjerløv et al., 2003; Benstead et al., 2009). As a consequence, presence/absence information and not abundances were used in statistical tests. Furthermore, in order to avoid drawbacks due to the different 
taxonomic resolution, statistical analyses were generally performed by using a standardised taxonomic level (family data). Information about genus was included instead to improve ecological trait data analyses (see later).

The effects of seasonality and type of environments (predefined zones) on family richness were tested by using ANOVA analysis on the log transformed data.

The quality of taxa inventory generated by seasonal sampling along the entire Oglio River and for the 3 groups of stations was checked using accumulation's curves. This approach is widely used to evaluate the representativeness of collected information (Soberón and Llorente 1993) and represents how the number of taxa within a geographical area varies as a function of the collection effort (Colwell and Coddington 1994). The slope of the curve decreases with sampling effort and reaches a hypothetical value of 0 when all taxa are detected. As the taxon richness is probably the main variable describing community diversity (Gaston 1996), accumulation's curves allow one to set reference terms for taxa richness given a fixed number of replicate samples. Different types of functions were fitted to family accumulation curves and the Weibull function provided the best match. The same function was demonstrated as a good compromise between the number of parameters to be fitted and also results in other studies on invertebrates (Jimenez-Valverde et al., 2006; Tjørve 2003). The Weibull function was fitted to smoothed data and the asymptotic value (i.e., the taxa richness predicted for an ideally infinite sample size) was computed. The ratio of recorded to predicted richness (asymptotic score) was used as a proxy of representativeness of the database (in the three pre-defined zones and for the whole river).

A nonmetric multidimensional scaling (nMDS) analysis was performed to identify distribution patterns among the macroinvertebrate communities of the different sampled sites.

NMDS is regarded as one of the most robust unconstrained ordination methods (Oksanen 2011) and is robust from deviation from multi-normality. Bray-Curtis distance was used as dissimilarity measure and stress was used to test the goodness of fit. The threshold above which the ordination was not considered reliable was set at $20 \%$. Linear fittings were performed between the hydrological data (discharge, velocity and depth) and the output of nMDS ordination in order to identify environmental factors driving macroinvertebrate distribution. Analysis of similarities (ANOSIM) using Bray-Curtis distance was carried out to test whether there was a significant difference between the a priori proposed zones in terms of macroinvertebrate communities. This test was developed by Clark (1993) as a method for testing the significance of the groups that had been a priori defined. Prior to multivariate analysis, hydrological variables were transformed (logtransformation for quantitative variables) and standardised to improve linear relationships among variables, reduce distribution skewness and avoid distortions due to the effect of different transformations and magnitudes. 
IndVal analysis was carried out to select the indicator family for each river zone (Dufrêne and Legendre 1997). This analysis evaluates the affinity of each taxon for one of the three environment types defined a priori (the Indicator Value: IV). Such an affinity is calculated on the basis of the frequency of each taxon in the identified groups. To take into account the unequal size of the sampling sites within each group the group-equalized IV was calculated according to De Cáceres and Legendre (2009). The significance of IV was tested using a Monte-Carlo test (999 runs) and Alpha level was set at 0.05. Taxa selected by IndVal should present environmentalspecific ecological traits to allow their presence; the "4th Corner Method" (Legendre et al., 1997) was used to check for differences in ecological traits between the different tested zones and flow conditions.

The matrix of ecological traits was built considering the traits and relative subgroups described by Usseglio-Polatera et al. (2000) and Tachet et al. (2002). The ecological characteristics used include the 7 traits related with hydrology and physical habitat, with a total of 37 possible modalities. The purpose of this method is to relate the ecological traits of the organisms to the habitat characteristics of the sites in which they live. The calculation is made possible by using traits, presence/absence (or abundance) and environmental matrices. Within the 5 models proposed by Dray \& Legendre (2008) model number 2 "Environmental control over species assemblage" was chosen. In this model, the hypothesis is that taxa assemblages depend on the environmental feature characterising the sites where they were found. As shown by some authors (Bournaud et al., 1996; Dolédec et al., 1998) higher taxonomic levels can be suitable for an ecological study, so the first step was to select the families and genus collected in the Oglio River from the database. For the macroinvertebrate groups in which genus data were available, only the genus recovered in Oglio River were used. The second step was to calculate the relative frequency of each subgroup (i.e. lowlands, piedmont level or alpine level) belonging to a category (i.e. Altitude). The sum of the frequencies of the subgroup within a category is equal to 1 .

\section{Results}

\section{Assessment of macroinvertebrate richness among different sampling methods}

Results from ANOVA analysis (Table 2$)$ suggested that the zone $(p<0.01)$ and the season $(p$ $<0.05)$ were statistically significant variables affecting macroinvertebrate family richness along the Oglio River but not the interaction zone:season $(p=0.09)$. During the study period (1 year) about 40,000 organisms were identified to family or genus level and a total of 72 families were identified. 
were presented in Surber samples and also in AS samples. Concretely 62 families were detected using AS while 57 using Surber net and 47 were presented using both methods. The families recorded by exclusively a method were rare and were found in only few sites.

Assessment of macroinvertebrate inventory completeness and richness estimations along the three proposed zones

Downstream and free flowing zones hosted the richest sampling stations, with a total of 61 and 55 families recorded. On the other hand, stations within dammed zones exhibited the lowest richness, with 37 families recorded. Accumulation's curves showed the representative sampling effort for the 3 selected zones (Fig 2). This result suggested that the sampling effort accounted for at least $75 \%$ of the total families estimated for each zone (Table 3). Family richness seemed to increase slightly more rapidly in the downstream sites compared to the other zones. Moreover, dammed sites presented clearly lower family richness values compared to the other zones that appeared to be rather similar. Using data from all pooled sampling stations, the ratio between the recovered (72) and theoretical number of families predicted by accumulation's curves (78) equalled

Importance of hydromorphological environmental variables in determining macroinvertebrate communities

In the ordination space of the first 3 axes of non-multidimensional scaling the samples were arranged according to the a priori identified zones (Fig.3) and presented a stress value of $16 \%$. Moreover, vector fitting among nMDS axes and hydromorphological parameters highlighted the importance of hydrological factors as drivers of the macroinvertebrate communities. The nMDS plot established three distinct groups that essentially consisted of the proposed a priori hypothesis. Considering axes 1 and 2, "dammed stations" appeared well-clustered on the right side of the plot while "downstream stations" were placed on the bottom and "free flowing section" essentially on the top left of the plot.

In detail (Fig. 3), downstream stations seemed to be characterised by reduced discharge and depth and partially by high velocity, while dammed ones were related to higher levels of depth. On the other hand, stations in the free flowing section were mainly characterised by high discharges

312 selected zones. Furthermore, the ANOSIM test showed there were significant differences $(\mathrm{R}=$ $3130.522, p<0.001)$ in macroinvertebrate assemblage composition among the three pre-defined zones. 
IndVal analysis identified indicator taxa for the three environment types proposed (Table 4).

317 Five families were significant indicators for dammed sites: Ecnomidae, Coenagrionidae,

318 Viviparidae, Lymnaeidae and Limnephilidae. Some authors (Bonada et al., 2008, following Dufrêne

319 and Legendre, 1997) considered an IV > 25 as key value to consider adequate an indicator taxa, so

320 the first two presented an important IV value and great significance level $(p<0.001)$. Stations

321 included in the downstream zones presented a heterogeneous list composed by fourteen indicator

322 families: Limoniidae, Psychomyidae, Lumbricidae, Baetidae, Neritidae and Rhyacophilidae with

323 the best significance level $(p<0.001)$. These stations presented a heterogeneous clustering of taxa,

324 with different ecological characteristics and varying taxonomic positions. Finally, seven families

325 were good indicators for the free flowing section with Heptageniidae (essentially genus

326 Heptagenia) with the highest IV followed by Calopterygidae (genus Calopteryx), Gammaridae,

327 Platycnemidae, Hydropsychidae, Gomphidae and lastly Tubificidae.

328 Results from the "4th Corner Method" showed distinct patterns of ecological traits in the

329 three different a priori hypothesised zones: dammed, downstream and free flowing stretch (Table

330 5). When focussing upon ecological traits like transversal distribution, longitudinal distribution or

331 current velocity it is very interesting to note that the three pre-defined zones presented

332 macroinvertebrate communities with different ecological traits. In these cases, dammed and

333 downstream zones presented almost always opposite and complementary values. In particular,

334 analysing transversal distribution in dammed zones presented a macroinvertebrate community with

335 negative correlation with habitats like river channel and a strong and positive relation with habitats

336 like ponds and pools $(0.25 ; p<0.01)$ and also with lakes $(0.07 ; p<0.01)$. On the other hand,

337 macroinvertebrate communities inhabiting downstream zones presented a negative relationship with

338 habitats like lakes $(-0.09 ; p<0.01)$ and ponds $(-0.11 ; p<0.05)$ and positive value with banks habitats

$339(0.12 ; p<0.01)$. In free flowing section significant and negative relationships were obtained with

340 ponds $(-0.10, p<0.05)$ and temporary waters $(-0.09 ; p<0.01)$. Focussing on longitudinal distribution

341 dammed zones presented negative relationship with crenon and epirhithron zones $(-0.11$ and -0.21 ;

$342 p<0.01)$ and positive relationship with metapotamon habitats $(0.17 ; p<0.01)$. Again, downstream

343 zones presented opposite values compared with dammed stations (except for estuary value) with

344 positive relationships with crenon and epirhithron areas $(0.09$ and $0.12 ; p<0.01)$ and negative

345 relationships with epipotamon $(-0.08 ; p<0.01)$ and metapotamon $(-0.08 ; p<0.05)$. In this ecological

346 trait free flowing sites presented complex results with positive relationships with metarhithron

347 zones $(0.11 ; p<0.01)$ and negative with estuary $(-0.12 ; p<0.01)$ and metapotamon $(-0.06 ; p<0.05)$.

$348 \quad$ Also considering altitude trait, macroinvertebrate communities inhabiting dammed and

349 downstream zones presented opposite signs between lowlands, piedmont and alpine levels. 
350

351

352

353

354

355

356

357

358

359

360

361

362

\section{3}

364

365

366

367

368

369

370

371

372

373

374

Observing substrate preference dammed zones were essentially related to microphytes and macrophytes $(0.14$ and $0.12 ; p<0.01)$, while downstream zones with flags, twigs and roots $(0.07$ and $0.09 ; p<0.01)$ and silt $(-0.09 ; \mathrm{p}<0.01)$. The free flowing section was positively related to silt, sand and gravel $(0.14 ; 0.12 ; 0.09$ with $p<0.01)$. Furthermore, considering current velocity, dammed zones presented negative and significant relationships with medium and fast velocity $(-0.18$ and -0.24 ; $p<0.01)$ while the others presented a positive relation, although less significant. Analysing the trophic status, it was interesting to note that dammed zones were positively related with eutrophic conditions $(0.13 ; p<0.01)$ while the other ones presented opposite results with negative relationship with eutrophic conditions. The temperature trait seemed important because dammed zones presented a negative and significant relationship with psychrophilic, i.e. cold-stenothermal organism $(-0.099 ; p<0.01)$ and a positive relationship with eurythermic conditions $(0.06 ; p<0.01)$, while other zones did not present significant values.

\section{Discussion}

Species level resolution is preferable in ecohydrological researches when it is available (Monk et al. 2012). However, the present study considered the taxonomic level used as adequate in order to characterise the ecological traits of most groups with respect to riverine hydrology and a good compromise between classification effort and gathered information (Marchant et al., 1995; Bournaud et al., 1996; Dolédec et al., 1998). Also, macroinvertebrate family richness generally presents a high correlation with species richness in Mediterranean areas (Sánchez-Fernández et al., 2006) as well as in boreal systems (Heino and Soininen, 2007) which seems to suggest how specieslevel assemblage patterns could be reproduced by using genus- and family-level data. Furthermore, recently Belmar et al. (2012) focussed on hydrological variables found a relatively strong relationship between community composition and flow regimes at different taxonomic levels, from species to family level.

In this study, the decision to work on the presence/absence of families and not on abundance is justified first by the necessity of using two distinct sampling techniques which were demonstrated to recover the same group of organisms. Additionally, outputs from the NMDS analysis were likely to provide a similar qualitative data ordination when performed on abundance (after data transformations as Wisconsin double standardization) and on presence/absence.

At the scale of the entire river, the seasonal samplings and the number of stations investigated were adequate in order to provide a reliable inventory of the macroinvertebrate community. In fact, according to the outputs of the accumulation's curves, more than $80 \%$ of the total families were censused, and only a few families were missing in order to reach the asymptotic theoretical richness value. Focussing on each environment type, about $78 \%$ of the expected families 
were found in dammed stations, and it is likely that sampling efforts could have been slightly improved in order to reach higher completeness values (Jiménez-Valverde and Hortal 2003; Sánchez-Fernandez et al., 2008). Highly representative family inventories were instead realised for downstream and free flowing stations.

The representativeness of the macroinvertebrate community for the entire river and for the three groups of a priori selected reaches is an important requirement for the analyses performed and guarantees the robustness of the main outputs. Results from the present study clearly suggest that hydrological parameters and regulated flows play a key role in structuring macroinvertebrate communities in a regulated lowland river. This outcome has a high degree of novelty as, to current knowledge, similar results focussing on large scale and entire river units, specifically on macroinvertebrate communities and ecological traits are very scarce in the literature, at least in ecohydrology research and similar geographic areas.

The sequence of hydropower plants, low head dams and water abstraction infrastructures has created a discontinuum of hydrological conditions in the Oglio River with alternating lentic-like and strictly lotic-like reaches near upstream and downstream infrastructures. As a consequence, macroinvertebrate communities do not present an upstream-downstream gradient along the rivercourse, as predicted by river continuum theories (Vannote et al., 1980). Rather, the presented results clearly describe identifiable and alternating lentic and lotic communities along the rivercourse. The results of NMDS analysis match the proposed a priori grouping of the investigated stations according to three distinct hydrological features. Differences in terms of taxonomic composition among the proposed zones were also reflected in the ANOSIM test while environmental types (predefined zones) and the season seems to be important factors affecting macroinvertebrate richness values.

These different zones will be discussed separately later. The macroinvertebrate community structure is probably shaped by factors such as the substrate, vegetation and chemical gradients at the microscale (i.e. dissolved oxygen availability in porewaters), that are directly related with local hydrology. Furthermore, hydrological change and interaction with substrate may affect the availability of potential microhabitats to some species while increasing habitat availability for others (Statzner et al., 1988). Gore et al. (2001) stressed that aquatic organisms are probably restricted to those combinations of velocity, depth, and substrate that allow morphological and behavioural resistance to flow to be exceeded by energetic gains and predicted an increasing emphasis on incorporating hydraulic variables as a part of bioassessment. A dynamic and natural hydrological connectivity among waterbodies, in terms of space and time, has been proven to drive patterns of macroinvertebrate biodiversity and ecosystem functions in different floodplain rivers (Amoros and Bornette 2002; Leigh and Sheldon 2009). 


\section{Dammed stations}

This group included sites characterised by features typical of shallow lakes of a few meters depth, no apparent water velocity, soft substrate and dense macrophyte stands. Here, hydrology and depth were the main drivers for the ordination of data (cluster on the right of the nMDS plot). Indicator taxa like Ecnomus tenellus (Ecnomidae) or Coenagrionidae, Viviparidae and Lymnaeidae were in agreement with this output, with absence of water current and high depth as selecting factors for the taxa colonizing dammed stations. Ecological trait analysis added further evidence in this respect, as recovered macroinvertebrate communities are generally related to lentic habitats like ponds or lakes with null current velocity and macro and microphytes substrate. Among macrophytes, Vallisneria spiralis was abundant in all dammed stations. Despite the fact that they were located in the upper zone of the Oglio River these sites did not present invertebrate communities typical of rhithron zones. This is in part due to the natural conditions of the lowland river, but considering the hydromorphologic variable values, it seems to be clear that regulated flows and dams act as alterations within the natural river continuum.

Here, the Oglio River is also often disconnected from its floodplain, although the ecological importance of this area as part of a river ecosystem has been recognised (Burt et al., 2008; Burt et al., 2010).

Stations upstream from hydropower plants and low head dams had poorer measured and estimated biodiversity, probably due to net habitat loss during the shift from a lotic to an artificial lentic system (Bonada et al., 2005; Ribera 2008) that included reduced sinuosity and the loss of meandering zones loss (Garcia et al., 2012). Aquatic environments such as rivers display large habitat heterogeneity, including pool-riffle sequences (Vannote et al., 1980; Allan and Castillo 2007) as well as a number of different micro-habitats at reach scale (Cogerino et al., 1995; Allan et al., 1997; Boyero 2003). The habitat heterogeneity of lotic ecosystems may allow the presence of a higher number of taxa in comparison to ponds or lakes, although under natural conditions, these environments generally contribute to the presence of rare and unique species (Williams et al., 2003). Furthermore, dammed stations, essentially in the upper zone of Oglio River, presented macroinvertebrate communities negatively related with psychrophilic conditions, which seems to emphasise the importance of thermal regimes (Olden and Naiman 2010) in environmental flows assessments.

\section{Downstream stations}

Current velocity, reduced depth and type of substrate (mainly flags or mesolithal) suggested that stations downstream from the dams or water abstraction structures had those features that characterise pristine, rhithral and stream-like environments. This is another artificial condition 
which is a consequence of a sudden decrease in water flow for multiple water uses. The reversal of lentic-like features and the re-establishment of lotic characteristics were described in the Serial Discontinuity Concept (SDC) (Ward and Stanford 1983) and in other studies (Odum 1997). The SDC viewed dams as clear discontinuities within the river continuum and proposed that rivers have a tendency to reset ecological conditions toward unregulated or natural conditions as distance downstream from the point of regulation increases (Stanford and Ward 2001).

In downstream stations, selected indicator families like Psychomyidae, Ephemerellidae (Ephemerella) or Rhyacophilidae were typical of rhithral ecosystems, while other families provided multiple and often unclear information with respect to environmental features. For example, the presence of Neritidae (Theodoxus) and other Mollusca could be an indicator of an hyporhithral or potamal environment, while that of Dreissena polymorpha does not, and its presence is probably due to a drift effect from dammed upstream coupled with the high dispersive capacity of this invasive species.

The ecological traits analysis, and in particular the traits transversal distribution, longitudinal distribution, current velocity and altitude suggested negative relationships between macroinvertebrate communities of downstream stations with lakes, potamal zones and null velocity and positive relation with alpine level altitude, fast velocity and rhithron zones, features that are generally typical of stream-like environments with limited water discharge.

\section{Free flowing stations}

These stations characterised a lowland, $\sim 100 \mathrm{~km}$ long free-flowing river course which was devoid of infrastructures that created longitudinal discontinuities of relevant water flow variations. Flows and water velocity were constant or tended to increase and the upstream-downstream variations of chemical and biological features probably followed the predictions of the Vannote $e t$ al. (1980) conceptual model.

Due to its length, this reach included a number of different habitats whose features could partially overlap those characterising downstream stations (i.e. the substrate, at its beginning) as well as those characterizing dammed stations (i.e. water depth, toward its end). Such heterogeneity is reflected by the results of the IndVal and Ecological traits analyses. In fact, selected macroinvetebrate indicators taxa of free flowing stations like Gammaridae, Heptagenia or different taxa of Odonata are essentially related with lowland rivers. However, results from the ecological trait analysis, and in particular those related to the trait longitudinal distribution, suggested a rhithral more than potamal macrofauna community. In terms of altitude traits, this section presented a macroinvertebrate fauna more related with a piedmont level community than with a lowland level. The use of different analysis (IndVal and traits analysis) can improve the quality of the results 
bringing additional ecohydrological information. This section that would be expected to present macroinvertebrate communities closely related with a potamon condition, really presented heterogeneous communities that may be partially associated with an alteration of the rhithronpotamon boundary. The topic regarding a possible shift in the rhithron-potamon boundary was in part stressed by Stanford et al. (1996) who suggested that in rivers that are free flowing for long distances downstream from large dams, the position of the rhithron-potamon transition could be predicted from the operational mode of the dams relative to the influence of tributaries. Furthermore this topic is quite specific and necessarily requires supplementary researches.

\section{Final considerations}

The relationship between habitat alteration and river ecology is finally receiving increasing attention (Vaughan et al., 2009; Poff and Zimmerman 2010) and specific macroinvertebrate index or invertebrate preferences research, related to flow alteration and hydroecology topics, have been recently developed (Extence et al., 1999; Mérigoux et al., 2009; Armanini et al., 2011a, Armanini et al., 2011b). However, biomonitoring activities by environmental agencies and scientific interest focus widely on the impact of dams and hydroelectric plants on downstream sections (Ligon et al., 1995; Power et al., 1996; Galbraith and Vaughn 2011) while less attention to the macroinvertebrate communities is generally devoted for upstream, dammed stations. Here, drastic changes in macroinvertebrate communities can occur, as demonstrated by the present study in terms of indicator taxa and selection of different macroinvertebrate ecological traits. The authors suggest that monitoring activities should also prioritise those zones where human intervention has created river reaches with lentic features. Pringle (1997), focussing on fish communities, had already stressed the importance of considering the upstream as well as downstream effects of dams and impoundments because disturbances can also be transmitted upstream.

Results from the present study also suggest altered macrofauna communities in zones located upstream and downstream from barriers or dams. For example, abundant densities of exotic invertebrates like Dreissena polymorpha, Corbicula or Orconectes limosus characterising dammed and downstream stations, are likely a consequence of flow alteration (Bunn and Arthington 2002) coupled with other anthropogenic causes. Upstream, invertebrate communities suffer stagnation and habitat loss, resulting in biodiversity loss (Stanford et al., 1996) as more exigent, strictly lotic taxa such as most EPT taxa (Ephemeroptera, Plecoptera, Trichoptera) cannot cope with such conditions. Downstream, macroinvertebrate communities suffer highly artificial variable flows, resulting in habitat instability that promotes the presence of communities with numerous indicator taxa. 
525 informative, with this respect, are those macroinvertebrate taxa characterised by high indicator 526 values.

Ecohydrological research and sustainable water flow management should be central in the present and near future in order to achieve the quality targets set by the Water Framework Directive (Acreman and Ferguson 2010; Boon et al., 2010) as well as for modified waterbodies such as the

530 Oglio River. This is particularly important also because hydroclimatic models predict that European 531 rivers will collectively show reduced discharge and seasonally would have lower summer flow

532 (Arnell 1999). Moreover, flow management may even be relatively ineffective in restoration

533 solutions or environmental conservation when provided in the absence of pollution abatement, 534 riparian management and habitat restoration (Arthington et al., 2010).

Renöfalt et al. (2010) have suggested prioritising among different restoration actions,

536 starting with projects that have positive effects on the largest areas or on projects and actions that 537 can serve as learning experiences through scientific experimentation and testing. In this perspective, 538 the investigated area from a human-dominated landscape should be exploited as useful test case 539 (Jackson et al., 2009) for the sustainable management of environmental flow and restoration of 540 floodplains in other similarly altered areas.

\section{Acknowledgments}

543 The authors wish to thank the director and employees of "Consorzio dell'Oglio" for their generous

544 support in the field work and Professor P. Viaroli, S. Leonardi and MC Naldi for their useful

545 suggestions. Thanks to U. Marzocchi, R. Bolpagni, D. Longhi, Rino, C. Ribaudo, E. Soana and E.

546 Famea for their assistance in the field work and to two anonymous referees for generously

547 improving the manuscript. The authors also would like to thank all of the members of the "Ecología

548 Acuática” Research Group (UMU). 


\section{References}

552 Acreman MC, Ferguson AJD. 2010. Environmental flows and the European Water Framework 553 Directive. Freshwater Biology 55: 32-48.

Allan JD, Castillo MM. 2007. Stream Ecology: structure and function of running waters. 2nd ed. Springer, Dordrecht, Holland.

Allan JD, Erickson DL, Fay J. 1997. The influence of catchment land use on stream integrity across multiple spatial scales. Freshwater Biology 37: 149-162.

Amoros C, Bornette G. 2002. Connectivity and biocomplexity in waterbodies of riverine floodplains. Freshwater Biology 47: 761-776.

Armanini DG, Horrigan N, Monk WA, Peters DL, Baird DJ. 2011a. Development of a benthic macroinvertebrate flow sensitivity index for Canadian rivers. River Research and Applications 27: 723-737.

Armanini DG, Monk WA, Tenenbaum DE, Peters DL, Baird DJ. 2011b. Influence of runoff regime type on a macroinvertebrate-based flow index in rivers of British Columbia (Canada). Ecohydrology. DOI: 10.1002/eco.234

Armitage PD. 1984. Environmental changes induced by stream regulation and their effect on lotic macroinvertebrate communities. In Regulated Rivers, (Eds Lillehammer A, Saltveit SJ) pp. 139165. Oslo University Press, Oslo, Norway.

Arnell NW. 1999. The effect of climate change on hydrological regimes in Europe: a continental perspective. Global Environmental Change 9: 5-23.

Arthington AH, Naiman RJ, McClain ME, Nilsson C. 2010. Preserving the biodiversity and ecological services of rivers: new challenges and research opportunities. Freshwater Biology 55: 116.

Battegazzore M, Guzzini A, Pagnotta R, Marchetti R. 1995. The importance of investigatory and analytical techniques in biological water-quality investigations. In The Ecological Basis for River Management, (Eds Harper DM, AJD Ferguson) pp. 193-209. John Wiley \& Sons, New York, USA.

Belmar O, Velasco J, Gutierrez-Canovas C, Mellado-Díaz A, Millan A. 2012. The influence of natural flow regimes on macroinvertebrate assemblages in a semiarid Mediterranean basin. Ecohydrology DOI: 10.1002/eco.

Benstead J, March JG, Pringle CM, Ewel KC, Short JW. 2009. Biodiversity and ecosystem function in species-poor communities: community structure and leaf litter breakdown in a Pacific island stream. Journal of the North American Benthological Society 28: 454-465.

Bo T, Fenoglio S, Malacarne G, Pessino M, Sgariboldi F. 2007. Effect of clogging on stream macroinvertebrates: an experimental approach. Limnologica 37: 186-192.

Boon PJ, Holmes NTH, Raven PJ. 2010. Developing standard approaches for recording and assessing river hydromorphology: the role of the European Committee for Standardization (CEN). Aquatic Conservation: Marine and Freshwater Ecosystems 20: S55-S61.

Bonada N, Zamora-Muñoz C, Rieradevall M, Prat N. 2005. Ecological and historical filters 
constraining spatial caddisfly distribution in Mediterranean rivers. Freshwater Biology 50: 781797.

Bonada N, Rieradevall M, Dallas H, Davis J, Day J, Figueroa R, Resh VN, Prat N. 2008. Multiscale assessment of macroinvertebrate richness and composition in Mediterranean-climate rivers. Freshwater Biology 53: 772-788.

Bournaud M, Cellot B, Richoux P, Berrahou A. 1996. Macroinvertebrate community structure and environmental characteristics along a large river: congruity of patterns for identification to species or family. Journal of North American Benthological Society 15: 232-253.

Boyero L. 2003. Multiscale patterns of spatial variation in stream macroinvertebrate communities. Ecological Research 18: 365-379.

Brooks AJ, Haeusler T, Reinfelds I, Williams S. 2005. Hydraulic microhabitats and the distribution of macroinvertebrate assemblages in riffles. Freshwater Biology 50: 331-344.

Buffagni A, Erba S. 2007. Macroinvertebrati acquatici e Direttiva 2000/60/EC (WFD). Parte A. Metodo di campionamento per i fiumi guadabili. Notiziario dei Metodi Analitici, Vol 1. IRSA-CNR, Roma, Italy.

Buffagni A, Erba S, Aquilano G, Armanini D, Beccari C, Casalegno C, Cazzola M, Demartini D, Gavazzi N, Kemp JL, Mirolo N, Rusconi M. 2007. Macroinvertebrati acquatici e Direttiva 2000/60/EC (WFD). Notiziario dei Metodi Analitici, Vol. 1, IRSA-CNR, Roma, Italy.

Bunn SE, Arthington AH. 2002. Basic principles and ecological consequences of altered flow regimes for aquatic biodiversity. Environmental management 30: 492-507.

Burt T, Hefting MM, Pinay G, Sabater S. 2008. The role of floodplains in mitigating diffuse nitrate pollution, in hydroecology and ecohydrology: past, present and future (eds PJ Wood, DM. Hannah and JP Sadler), John Wiley \& Sons, Ltd, Chichester, UK.

Burt T, Pinay G, Sabater, S. 2010. What do we still need to know about the ecohydrology of riparian zones? Ecohydrology 3: 373-377

Cairns JJR, Dickson KL. 1971. A simple method for the biological assessment of the effects of waste discharges on aquatic bottom-dwelling organism. Journal of Water Pollution Control Federation 43: 755-772.

Carling PA. 1992. The nature of the fluid boundary layer and the selection of parameters for benthic ecology. Freshwater Biology 28: 273-284.

Chessel D. 2011. ade4 package. Version 1.4-17. Analysis of Ecological Data: Exploratory and Euclidean methods in Environmental sciences. Documentation for R: a language and environment for statistical computing. R Foundation for Statistical Computing, Vienna, Austria (http://www.rproject.org).

Clarke KR. 1993. Non-parametric multivariate analyses of changes in community structure. Australian Journal of Ecology 18: 117-143.

Cogerino L, Cellot B, Bournaud M. 1995. Microhabitat diversity and associated macroinvertebrates in aquatic banks of a large European river. Hydrobiologia 304: 103-115. 
656 Colwell RK, Coddington JA. 1994. Estimating terrestrial biodiversity through extrapolation. 657 Philosophical Transactions Royal Society London 345: 101-118.

659 Copp GH. 1990. Effect of regulation on 0+ fish recruitment in the Great Ouse, a lowland river. Regulated Rivers: Research and Management 5: 251-263.

De Cáceres M, Legendre P. 2009. Associations between species and groups of sites: indices and statistical inference. Ecology 90: 3566-3574.

De Cáceres M. 2011. Indicspecies package. Version 1.5.2. Functions to assess the strength and significance of relationship of species site group associations. Documentation for R: a language and environment for statistical computing. R Foundation for Statistical Computing, Vienna, Austria (http://www.r-project.org).

Dolédec S, Statzner B, Frainay V. 1998. Accurate description of functional community structure: identifying stream invertebrates to species-level? Bulletin of North American Benthological Society 15: $154-155$.

Dray S, Legendre P. 2008. Testing the species traits-environment relationships: the fourth-corner problem revisited. Ecology 89: 3400-3412.

Dufrệne M, Legendre P. 1997. Species assemblages and indicator species: the need for a flexible asymmetrical approach. Ecological Monographs 67: 345-366.

Extence CA, Balbi DM, Chadd RP. 1999. River flow indexing using benthic macroinvertebrate: a framework for setting hydrobiological objectives. Regulated Rivers: Research and Management 15 : 543-574.

European Commission 2000. Directive 2000/60/EC of the European Parliament and of the Council of 23 October 2000 Establishing a framework for community action in the field of water policy official journal 22 December 2000 L 327/1. European Commission, Brussels.

Galbraith HS, Vaughn CC. 2011. Effects of reservoir management on abundance, condition, parasitism and reproductive traits of downstream mussels. River Research and Applications 27: 193-201

Garcia XF, Schnauder I, Pusch MT. 2012. Complex hydromorphology of meanders can support benthic invertebrate diversity in rivers. Hydrobiologia 685: 49-68.

Gaston KJ. 1996. Species richness: measure and measurement. In Biodiversity: a biology of numbers and difference. KJ Gaston (ed). Blackwell Science: Oxford; 77-113.

Gore JA, Layzer JB, Mead J. 2001. Macroinvertebrate instream flow study after 20 years: a role in stream management and restoration. Regulated rivers: Research and Management 17: 527-542.

Gjerløv C, Hildrew AG, Jones JI. 2003. Mobility of stream invertebrates in relation to disturbance and refugia: a test of habitat templet theory. Journal of the North American benthological Association 22: 207-223.

Heppner CS, Loague K, 2008. A dam problem: simulated upstream impacts for a Searsville-like watershed. Ecohydrology, 1: 408-424. 
Heino J, Soininen J. 2007. Are higher taxa adequate surrogates for species-level assemblage patterns and species richness in stream organisms? Biological Conservation 137: 78-89.

Irz P, Odion M, Argillier C, Pont D. 2006. Comparison between the fish communities of lakes, reservoirs and rivers: can natural systems help define the ecological potential of reservoirs? Aquatic Sciences 68: 109-116.

Jackson, RB, Jobbágy EG, Nosetto, MD. 2009. Ecohydrology in a human-dominated landscape. Ecohydrology 2: 383-389.

Jansson R, Nilsson C, Renöfält B. 2000. Fragmentation of riparian floras in rivers with multiple dams. Ecology 81: 899-903.

Jiménez-Valverde A, Hortal J. 2003. Las curvas de acumulación de especies y la necesidad de evaluar la calidad de los inventarios biológicos. Revista Ibérica de Aracnología 8: 151-161.

Jimenez-Valverde A, Mendoza S, Cano J, Munguira M. 2006. Comparing relative model fit of several species-accumulation functions to local Papilionoidea and Hesperioidea butterfly inventories of Mediterranean habitats. Biodiversity and Conservation 1: 163-176.

Kennen JG, Riva-Murray K, Beaulieu KM. 2010. Determining hydrologic factors that influence stream macroinvertebrate assemblages in the northeastern US. Ecohydrology 3: 88-106.

Laini A, Bartoli M, Castaldi S, Viaroli P, Capri E, Trevisan M. 2011. Greenhouse gases (CO2, CH4 and N2O) in lowland springs within an agricultural impacted watershed (Po River plain, northern Italy). Chemistry and Ecology 27: 177-187.

Legendre P, Galzin R, Harmelin-Vivien M. 1997. Relating behavior to habitat: solutions to the fourthcorner problem. Ecology 78: 547-562.

Leigh C, Sheldon F. 2009. Hydrological connectivity drives patterns of macroinvertebrate biodiversity in floodplain rivers of the Australian wet/dry tropics. Freshwater Biology 54: 549-571.

Lessard JL, Hayes DB. 2003. Effects of elevated water temperature on fish and macroinvertebrate communities below small dams. River Research and Applications 19: 721-732.

Ligon FK, Dietrich WE, Trush WJ. 1995. Downstream ecological effects of dams. BioScience 45 : 183-192.

Marchant R, Barmuta LA, Chessman BC. 1995. Influence of sample quantification and taxonomic resolution on the ordination of macroinvertebrate communities from running waters in Victoria, Australia. Marine and Freshwater Research 46: 501-506.

Mérigoux S, Lamouroux N, Olivier J, Dolédec S. 2009. Invertebrate hydraulic preferences and predicted impacts of changes in discharge in a large river. Freshwater Biology 54: 1343-1356.

Merritt RW, Lawson DL. 1992. The role of leaf litter macroinvertebrates in stream-floodplain dynamics. Hydrobiologia 248: 65-77.

Merritt RW, Cummins KW, Burton TM. 1984. The role of aquatic insects in the cycling of nutrients. In The Ecology of Aquatic Insects (Eds Resh VH, Rosenberg DM) pp. 134-163. Praeger Publishers, 
Monk WA, Wood PJ, Hannah DM, Extence CA, Chadd RP, Dunbar MJ. 2012. How does macroinvertebrate taxonomic resolution influence ecohydrological relationships in riverine ecosystems. Ecohydrology 5: 36-45.

Nilsson C, Berggren K. 2000. Alterations of riparian ecosystems caused by river regulation. BioScience 50: 783-792.

Odum EP. 1997. Ecology: a bridge between science and society. Sinauer Associates Incorporated. 330 pp. Sunderland, Massachusetts, USA.

Olden JD, Naiman RJ. 2010. Incorporating thermal regimes into environmental flows assessments: modifying dam operations to restore freshwater ecosystem integrity. Freshwater Biology 55: 86107.

Oksanen J. 2011. The Vegan package. Version 1.17-11. Community Ecology Package. Documentation for R: a language and environment for statistical computing. R Foundation for Statistical Computing, Vienna, Austria (http://www.r-project.org).

Pinardi M, Bartoli M, Longhi D, Viaroli P. 2011. Net autotrophy in a fluvial lake: The relative role of phytoplankton and floating-leaved macrophytes. Aquatic Sciences 73: 389-403.

Poff NL, Olden JD, Merritt DM, Pepin DM. 2007. Homogenization of regional river dynamics by dams and global biodiversity implications. Proceedings of the National Academy of Sciences of the United States of America 104: 5732-5737.

Poff NL, Zimmerman JH. 2010. Ecological responses to altered flow regimes: a literature review to inform the science and management of environmental flows Freshwater Biology 55: 194-205.

Power ME, Dietrich WE, Finlay JC. 1996. Dams and downstream aquatic biodiversity: potential food web consequences of hydrologic and geomorphic change. Environmental Management 20: $887-895$.

Pringle CM. 1997. Exploring how disturbance is transmitted upstream: Going against the flow. Journal of the North American Benthological Society 16: 425-438.

Pringle CM, Freeman MC, Freeman BJ. 2000. Regional effects of hydrologic alterations on riverine macrobiota in the new world: tropical-temperate comparisons. BioScience 50: 807-823.

R-Development-Core-Team. 2010. R: A Language and Environment for Statistical Computing, Vienna.

Rempel LL, Richardson JS, Healey MC. 2000. Macroinvertebrate community structure along gradients of hydraulic and sedimentary conditions in a large gravel-bed river. Freshwater Biology 45: $57-73$.

Renöfält BM, Jansson R, Nilsson C. 2010. Effects of hydropower generation and opportunities environmental flow management in Swedish ecosystems. Freshwater Biology 55: 49-67.

Ribera I. 2008. Habitat constraints and the generation of diversity in freshwater macroinvertebrates. In Aquatic insects: challenges to populations (ed. by J. Lancaster and R.A. Briers). CAB 
International, Wallingford, UK, pp. 289-311.

Rosenberg DM, McCully P, Pringle CM. 2000. Global-scale environmental effects of hydrological alterations: introduction. BioScience 50: 746-751.

Sánchez-Fernandez D, Abellán P, Mellado A, Velasco J, Millán A. 2006. Are water beetles good indicators of biodiversity in Mediterranean aquatic ecosystems? The case of Segura river basin (SE Spain). Biodiversity and Conservation 15: 4507-4520.

Sánchez-Fernández D, Lobo JM, Abellán P, Ribera I, Millán A. 2008. Bias in freshwater biodiversity sampling: the case of Iberian water beetles. Diversity and Distributions 14: 754-762.

Soana E, Racchetti E, Laini A, Bartoli M, Viaroli P. 2011. Soil budget, net export, and potential sinks of nitrogen in the lower Oglio River watershed (northern Italy). CLEAN-Soil, Air, Water 39: 956-965.

Soberón J, Llorente J. 1993. The use of species accumulation functions for the prediction of species richness. Conservation Biology 7: 480-488

Solimini AG, Gulia P, Monfrinotti M, Carchini G. 2000. Performance of different biotic indices and sampling methods in assessing water quality in the lowland stretch of the Tiber River. Hydrobiologia 422-423: 197-208.

Sparks RE. 1995. Need for ecosystems management of large rivers and their floodplains. BioScience 45: 168-182.

Stanford JA, Ward JV, Liss WJ, Frissell CA, Williams RN, Lichatowich JA, Coutant CC. 1996. A general protocol for restoration of regulated rivers. Regulated Rivers: Research and Management 12: $391-413$.

Stanford JA, Ward J. 2001. Revisiting the serial discontinuity concept. Regulated Rivers: Research and Management 17: 303-310.

Statzner B, Gore JA, Resh VH. 1988. Hydraulic stream ecology: observed patterns and potential applications. Journal of the North American Benthological Society 7: 307-360.

St. Louis VL, Kelly CA, Duchemin E, Rudd JWM, Rosenberg DM. 2000. Reservoir Surfaces as Sources of Greenhouse Gases to the Atmosphere: A Global Estimate. BioScience 50: 766-775.

Syvitski JPM, Vörösmarty CJ, Kettner AJ, Green P. 2005. Impact of humans on the flux of terrestrial sediment to the global coastal ocean. Science 308: 376-380.

Tachet H, Richoux P, Bournaud M, Usseglio-Polatera P. 2002. Invertébrés d'Eau Douce: systématique, biologie, écologie. CNRS éditions, Paris, France.

Tjørve E. 2003. Shapes and functions of species-area curves: a review of possible models. Journal of Biogeography 30: 827-835.

Usseglio-Polatera P, Bournaud M, Richoux P, Tachet H. 2000. Biological and ecological traits of benthic freshwater macroinvertebrates: relationships and definition of groups with similar traits. Freshwater Biology 43: 175-205. 
863 Vaughan IP, Diamond M, Gurnell AM, Hall KA, Jenkins A, Milner NJ, Naylor LA, Sear DA, 864 Woodward G, Ormerod SJ. 2009. Integrating ecology with hydromorphology: a priority for river 865 science and management. Aquatic Conservation: Marine and Freshwater Ecosystems 19: 113-125.

867 Vannote RL, Wayne Minshall G, Cummins KW, Sedell JR, Cushing CE. 1980. The River 868 Continuum Concept. Canadian Journal of Fisheries and Aquatic Sciences 37: 130-137.

870 Ward JV, Stanford JA. 1983. The serial discontinuity concept of lotic ecosystems. In Dynamics of 871 Lotic Ecosystems (Eds Fontaine TD, Bartell SM) pp. 29-42. Ann Arbor Science: Ann Arbor 872 Michigan, USA.

874 Ward JV, Stanford JA. 1987. The ecology of regulated streams: Past accomplishments and 875 directions for future research. In Regulated Streams Advances in Ecology (Eds Craig JF, Kemper 876 JB) pp. 391-409. Plenum Press, New York, USA.

Williams P, Whitfield M, Biggs J, Bray S, Fox G, Nicolet P, Sear D. 2003. Comparative biodiversity 879 of rivers, streams, ditches and ponds in an agricultural landscape in Southern England. Biological 880 Conservation 115: 329-341.

882 Zolezzi G, Siviglia A, Toffolon M, Maiolini B. 2011. Thermopeaking in Alpine streams: event characterization and time scales. Ecohydrology 4: 564-576. 
900 Table 1. Environmental and hydrological variables measured and used in the analysis.

901

\begin{tabular}{l|l|l|l|}
\hline \multicolumn{1}{c|}{ Variables } & $\begin{array}{l}\text { Dammed } \\
\text { stations }\end{array}$ & $\begin{array}{l}\text { Downstream } \\
\text { stations }\end{array}$ & $\begin{array}{l}\text { Free flowing } \\
\text { stations }\end{array}$ \\
\hline & & & \\
Discharge $\left(\mathrm{m}^{3} \mathrm{~s}^{-1}\right)$ & $42.88 \pm 27.72$ & $21.23 \pm 14.33$ & $86.23 \pm 54.53$ \\
Depth $(\mathrm{m})$ & $3.10 \pm 0.75$ & $1.13 \pm 0.49$ & $1.96 \pm 0.84$ \\
Velocity $\left(\mathrm{m} \mathrm{s}^{-1}\right)$ & $0.23 \pm 0.22$ & $0.51 \pm 0.32$ & $0.95 \pm 0.31$ \\
& & & \\
\hline
\end{tabular}

902

903

904

905

906

907

908

909

910

911

912

913

914

915

916

917

918

919

920

921

922

923

924

925

926

927

928

929

930

931

932

933

934

935

936

937

938

939

940

941

942

943 
944 Table 2. Summaries of ANOVA used to assess the effects of Zone, Season and the interaction on 945 macroinvertebrate richness. df: degrees of freedom. *** $p<0.001 ; * * p<0.01 ; * p<0.05$

946

\begin{tabular}{lcccc}
\hline Variables & df & Mean Sq & F-value. & $\boldsymbol{p}$-value \\
\hline Zone & 2 & 0.7403 & 6.206 & $0.00387^{* *}$ \\
Season & 3 & 0.3712 & 3.112 & $0.03425^{*}$ \\
Zone: Season & 6 & 0.2283 & 1.914 & 0.09634 \\
\hline
\end{tabular}


948 Table 3. Number of stations sampled (Stations), number of observed (S obs) and estimated families 949 (S exp) for each Oglio zone (obtained by Accumulation's Curves). For each zone the completeness 950 degree (\% Compl) is also displayed.

951

\begin{tabular}{lcccc}
\hline & Stations & S exp & S obs & \% Compl \\
\hline Dammed stations & 14 & 47 & 37 & 78
\end{tabular}

$\begin{array}{lllll}\text { Downstream stations } & 24 & 69 & 61 & 89\end{array}$

$\begin{array}{lllll}\text { Free flowing stations } & 25 & 65 & 55 & 84\end{array}$

$63 \quad 78$

72 92 
954 Table 4. Results of INDVAL analysis for each zone. Indicator Value and significant $p$-value are 955 displayed.

956

\begin{tabular}{|c|c|c|c|}
\hline \multicolumn{4}{|c|}{ Dammed stations } \\
\hline Order & Family & I.V. & $p$-value \\
\hline TRI & Ecnomidae & 64.3 & 0.001 \\
\hline ODO & Coenagrionidae & 38.6 & 0.001 \\
\hline ARC & Viviparidae & 25.5 & 0.004 \\
\hline PUL & Lymnaeidae & 25.0 & 0.024 \\
\hline TRI & Limnephilidae & 14.3 & 0.039 \\
\hline \multicolumn{4}{|c|}{ Downstrem stations } \\
\hline Order & Family & I.V. & $p$-value \\
\hline DIT & Limoniidae & 54.8 & 0.001 \\
\hline TRI & Psychomyidae & 53.7 & 0.001 \\
\hline OPI & Lumbricidae & 53.3 & 0.001 \\
\hline EFE & Baetidae & 46.0 & 0.001 \\
\hline NER & Neritidae & 42.0 & 0.001 \\
\hline EFE & Ephemerellidae & 40.7 & 0.002 \\
\hline VEN & Dreissenidae & 40.2 & 0.011 \\
\hline TRI & Rhyacophilidae & 39.9 & 0.001 \\
\hline TRI & Lepidostomatidae & 37.5 & 0.003 \\
\hline DIT & Empididae & 33.6 & 0.005 \\
\hline $\mathrm{ARH}$ & Erpobdellidae & 30.6 & 0.045 \\
\hline HEM & Naucoridae & 25.5 & 0.005 \\
\hline VEN & Corbiculidae & 24.1 & 0.044 \\
\hline DIT & Tipulidae & 17.4 & 0.04 \\
\hline \multicolumn{4}{|c|}{ Free flowing stations } \\
\hline Order & Family & I.V. & $p$-value \\
\hline EFE & Heptageniidae & 74.3 & 0.001 \\
\hline ODO & Calopterygidae & 49.0 & 0.001 \\
\hline ANP & Gammaridae & 48.0 & 0.004 \\
\hline ODO & Platycnemidae & 44.4 & 0.001 \\
\hline TRI & Hydropsychidae & 43.8 & 0.035 \\
\hline ODO & Gomphidae & 42.9 & 0.001 \\
\hline TUB & Tubificidae & 23.2 & 0.033 \\
\hline
\end{tabular}


960 Table 5. Summaries of ecological traits results following the traits description of Usseglio-Polatera 961 et al. (2000). The results from the global test (F) and their significance $p$ obtained by permutations 962 in the "4th Corner Method" are presented (Legendre et al., 1997). For dammed, downstream and 963 free flowing sites, the r-values from the correlation traits-habitat matrix are given. The significance 964 of r-value was also tested by permutations (999 runs). All $p$-values include Holm correction. *** $965 p<0.001 ; * * p<0.01 ; * p<0.05$

966

\begin{tabular}{|c|c|c|c|c|c|c|c|c|c|}
\hline \multirow{3}{*}{$\begin{array}{l}\text { Ecological Traits } \\
\text { Transversal distributior }\end{array}$} & \multirow[t]{2}{*}{ F-test } & \multicolumn{2}{|c|}{$p$-value } & \multicolumn{2}{|c|}{ Dammed } & \multicolumn{2}{|c|}{ Downstream } & \multicolumn{2}{|c|}{ Free flowing } \\
\hline & & & & & r-value & & r-value & & r-value \\
\hline & & & & & & & & & \\
\hline river_channel & 13.705 & 0.001 & $* * *$ & -0.159 & 0.003 & 0.054 & 0.034 & 0.072 & 0.016 \\
\hline banks__ & 15.167 & 0.001 & $* * *$ & -0.160 & 0.003 & 0.116 & 0.003 & 0.008 & 0.408 \\
\hline ponds_pools & 36.554 & 0.001 & $* * *$ & 0.255 & 0.003 & -0.107 & 0.014 & -0.095 & 0.014 \\
\hline marshes_peat_bogs & 1.284 & 0.126 & & 0.026 & 0.282 & 0.027 & 0.282 & -0.049 & 0.084 \\
\hline temporary_waters & 4.066 & 0.001 & $* * *$ & 0.032 & 0.098 & 0.060 & 0.016 & -0.088 & 0.003 \\
\hline lakes & 4.702 & 0.001 & $* * *$ & 0.071 & 0.004 & -0.087 & 0.003 & 0.034 & 0.113 \\
\hline groundwaters & 2.813 & 0.001 & $* * *$ & 0.016 & 0.208 & -0.071 & 0.003 & 0.061 & 0.003 \\
\hline \multicolumn{10}{|c|}{ Longitudinal distribution } \\
\hline crenon & 8.075 & 0.001 & $* * *$ & -0.113 & 0.003 & 0.093 & 0.003 & -0.005 & 0.417 \\
\hline epirhithron & 24.772 & 0.001 & $* * *$ & -0.210 & 0.003 & 0.120 & 0.003 & 0.045 & 0.106 \\
\hline metarhithron & 21.290 & 0.001 & $* * *$ & -0.191 & 0.003 & 0.038 & 0.120 & 0.114 & 0.003 \\
\hline hyporhithron & 6.407 & 0.001 & $* * *$ & -0.110 & 0.003 & 0.051 & 0.032 & 0.035 & 0.068 \\
\hline epipotamon & 4.446 & 0.009 & $* *$ & 0.073 & 0.014 & -0.082 & 0.009 & 0.026 & 0.194 \\
\hline metapotamon & 15.750 & 0.001 & $* * *$ & 0.171 & 0.003 & -0.080 & 0.022 & -0.055 & 0.034 \\
\hline estuary & 8.242 & 0.001 & $* * *$ & 0.040 & 0.037 & 0.088 & 0.003 & -0.124 & 0.003 \\
\hline outside_river_system & 17.688 & 0.001 & $* * *$ & 0.175 & 0.003 & -0.118 & 0.003 & -0.019 & 0.293 \\
\hline \multicolumn{10}{|l|}{ Altitude } \\
\hline lowlands & 9.678 & 0.001 & $* * *$ & 0.135 & 0.003 & -0.056 & 0.052 & -0.050 & 0.052 \\
\hline piedmont_level & 10.184 & 0.001 & $* * *$ & -0.135 & 0.003 & 0.033 & 0.129 & 0.075 & 0.008 \\
\hline alpine_level & 5.319 & 0.002 & $* *$ & -0.091 & 0.003 & 0.077 & 0.004 & -0.006 & 0.413 \\
\hline \multicolumn{10}{|c|}{ Substrate (preferendum) } \\
\hline flags & 3.083 & 0.005 & $* *$ & -0.001 & 0.487 & 0.069 & 0.004 & -0.071 & 0.003 \\
\hline gravel & 7.247 & 0.001 & $* * *$ & -0.099 & 0.003 & -0.013 & 0.324 & 0.093 & 0.003 \\
\hline sand & 12.812 & 0.001 & $* * *$ & -0.137 & 0.003 & -0.005 & 0.451 & 0.115 & 0.003 \\
\hline silt & 10.609 & 0.001 & $* * *$ & -0.064 & 0.004 & -0.085 & 0.004 & 0.140 & 0.003 \\
\hline macrophytes & 8.486 & 0.001 & $* * *$ & 0.120 & 0.003 & -0.019 & 0.230 & -0.078 & 0.006 \\
\hline microphytes & 10.592 & 0.001 & $* * *$ & 0.141 & 0.003 & -0.060 & 0.044 & -0.052 & 0.044 \\
\hline twigs_roots & 4.278 & 0.001 & $* * *$ & -0.054 & 0.010 & 0.088 & 0.003 & -0.049 & 0.011 \\
\hline organic_detritus & 0.774 & 0.164 & & 0.032 & 0.153 & -0.033 & 0.153 & 0.009 & 0.325 \\
\hline mud & 2.024 & 0.059 & 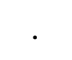 & 0.027 & 0.151 & -0.062 & 0.018 & 0.043 & 0.134 \\
\hline \multicolumn{10}{|c|}{ Current velocity (preferendum) } \\
\hline null & 31.875 & 0.001 & $* * *$ & 0.239 & 0.003 & -0.087 & 0.013 & -0.103 & 0.008 \\
\hline slow & 6.559 & 0.001 & $* * *$ & 0.107 & 0.003 & -0.020 & 0.200 & -0.066 & 0.004 \\
\hline medium & 35.694 & 0.001 & $* * *$ & -0.246 & 0.003 & 0.056 & 0.068 & 0.140 & 0.003 \\
\hline fast & 19.390 & 0.001 & $* * *$ & -0.189 & 0.003 & 0.087 & 0.008 & 0.062 & 0.022 \\
\hline $\begin{array}{l}\text { Trophic status (prefer } \\
\text { oligotrophic }\end{array}$ & 9.936 & 0.001 & $* * *$ & -0.133 & 0.003 & 0.086 & 0.006 & 0.018 & 0.266 \\
\hline
\end{tabular}




\begin{tabular}{l|ccc|cc|cc|cc} 
mesotrophic & 3.372 & 0.008 & $* *$ & 0.050 & 0.058 & -0.078 & 0.009 & 0.041 & 0.059 \\
eutrophic & 9.031 & 0.001 & $* * *$ & 0.130 & 0.003 & -0.047 & 0.041 & -0.056 & 0.024 \\
& & & & & & & & & \\
Temperature & 5.234 & 0.001 & $* * *$ & -0.099 & 0.003 & 0.043 & 0.062 & 0.036 & 0.066 \\
psychrophilic & 0.409 & 0.411 & & 0.024 & 0.333 & 0.003 & 0.446 & -0.022 & 0.333 \\
thermophilic & 2.153 & 0.032 & $*$ & 0.063 & 0.006 & -0.037 & 0.126 & -0.013 & 0.318 \\
eurythermic & & & & & & & &
\end{tabular}




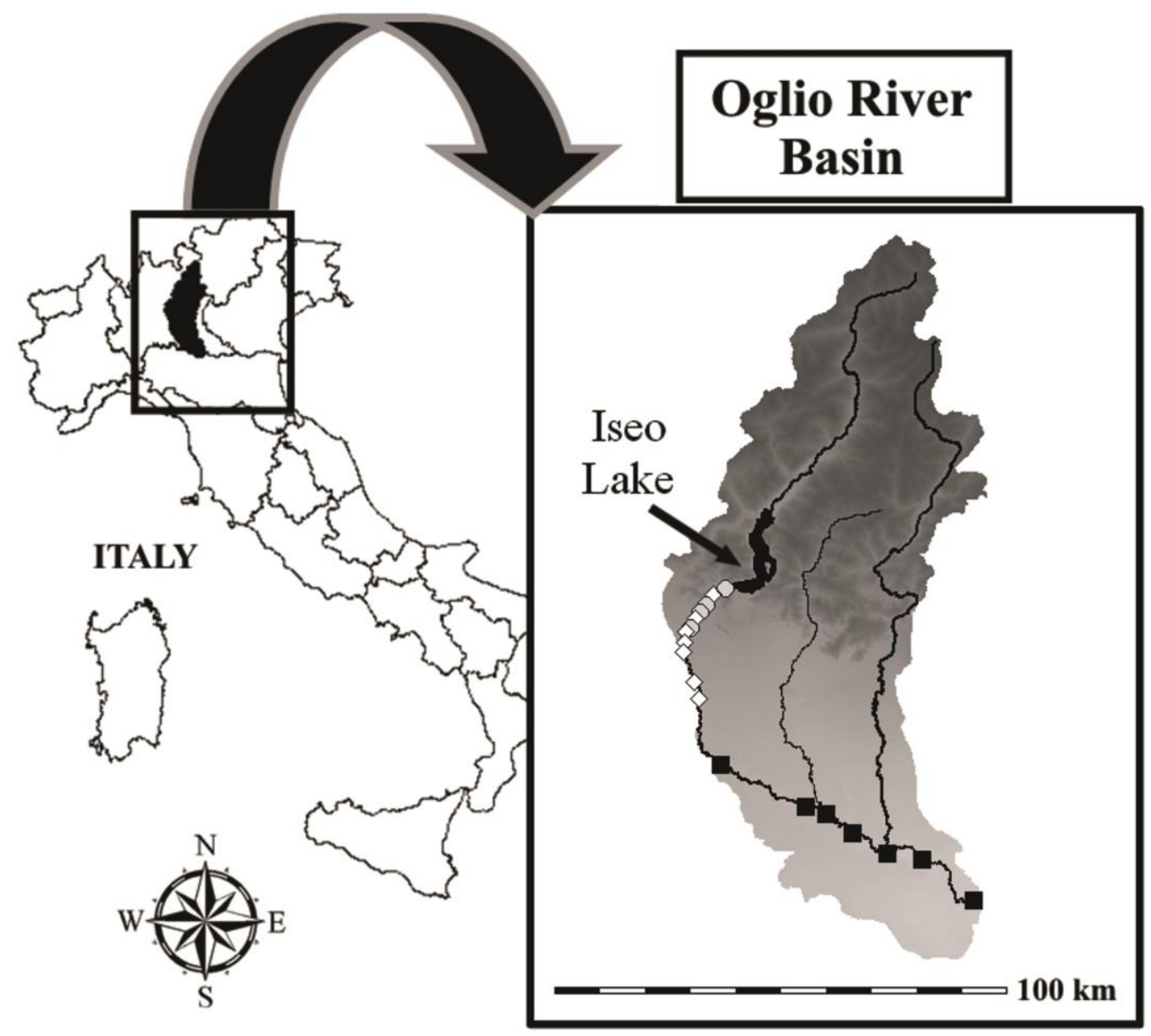

970

971

972 Fig 1. Map of Oglio basin (Northern Italy) and sampling sites along the river. In grey circles the

973 dammed sites, in white downstream sites and in black squares the sites belonging to the free

974 flowing section.

975

976

977 


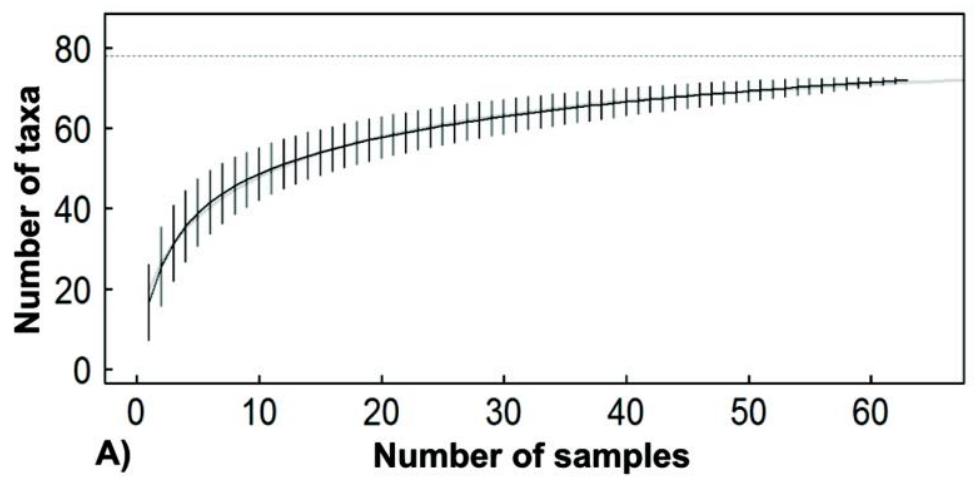

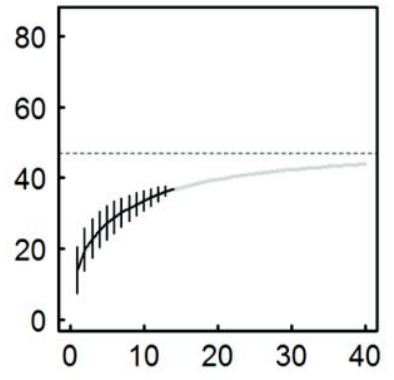

B)

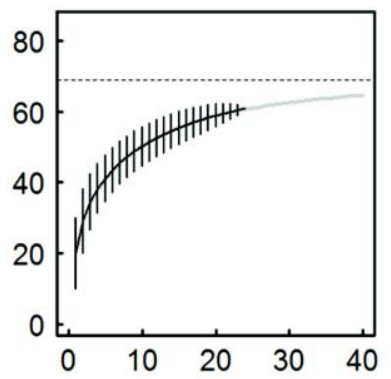

C)

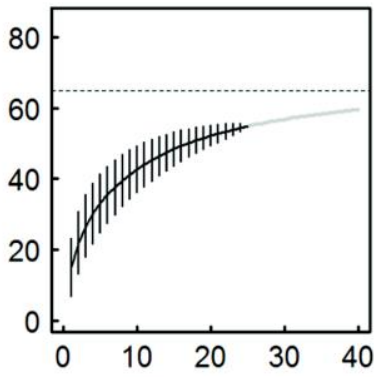

D)
Fig 2. Accumulation's Curves in the Oglio River (A). The three zones separately are also displayed: Dammed stations (B), Downstream stations (C) and free flowing section (D). Expected asymptote is always displayed. The numbers of samples are always displayed on the $\mathrm{x}$-axis while the number of taxa on the y-axis. 


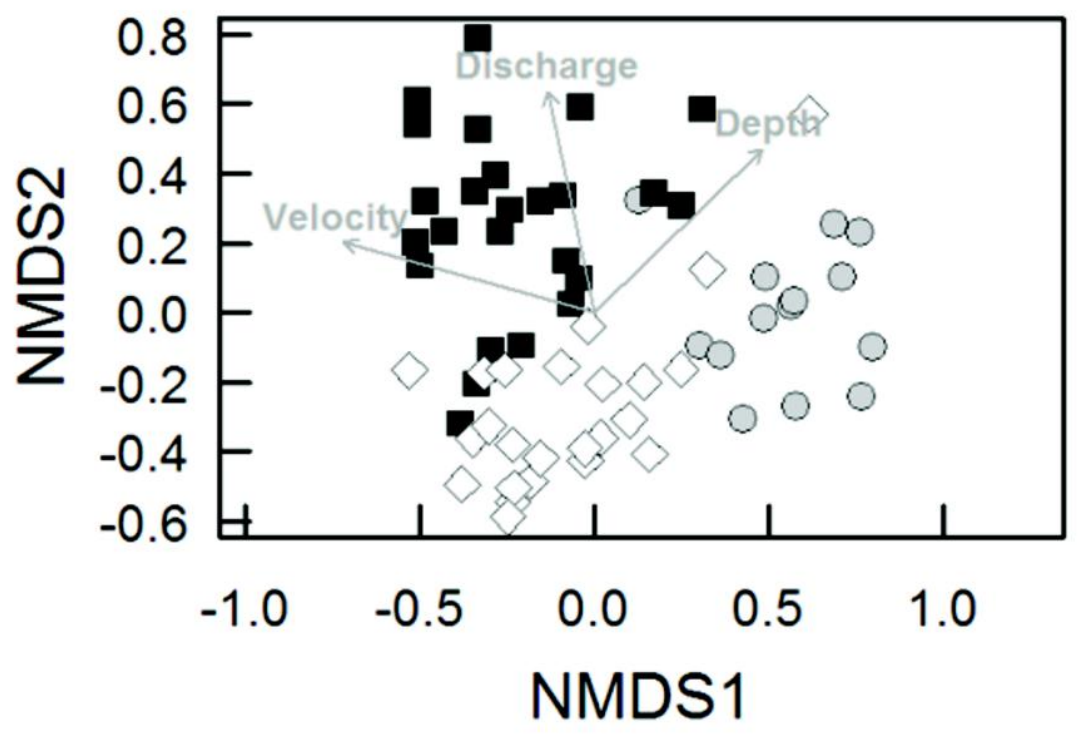

988 Fig 3. NMDS plot and the a priori identified zones coloured. In black color sites belonging to the 989 free flowing section, in grey dammed sites and in white downstream sites (stress=0.16).

990 Hydromorphological variables marked are also displayed.

991 [sf3] 